\title{
RELATIONSHIP OF AIR TEMPERATURE TO OUTBREAKS OF INFLUENZA
}

\author{
MARIAN L. DAVEY AND DANIEL REID* \\ Epidemiological Research Laboratory, Central Public Health Laboratory, London, \\ and Communicable Diseases Unit, Ruchill Hospital, Glasgow
}

The Encyclopaedia Britannica (1970) states that the term 'influenza' was introduced in 1743 by John Huxham who derived the word from the Italian phrase which ascribed the origin of the disease to 'un influenza di freddo', the influence of the cold. Since that time several workers have implicated inclement weather with an increased morbidity from influenza. In 1885, William Farr noted from the Registrar General's returns of deaths in England and Wales that 'the degree down to which monthly temperatures fall in December, January and February determine to a great extent the mortality of the winter'. More recently, Semple (1951) indicated that immediately before and during an influenza epidemic period Merseyside experienced the coldest spell for many years, the weekly mean temperature from mid-December to mid-January being 2.5 to $3.6^{\circ} \mathrm{C}$ below the mean temperature for the corresponding weeks during the previous 20 years. Unusually low temperatures were also noted shortly before an epidemic of influenza virus B in Glasgow in 1952 (Anderson et al., 1953).

During the past five years the United Kingdom has experienced winters of greatly differing degrees of severity and the incidence of influenza has varied from that of epidemic proportion to almost complete absence of the disease. Because of these wide ranges of temperature and illness, an attempt has been made to determine if there is a relationship between the prevailing atmospheric temperature and the occurrence of influenza.

\section{METHOD}

Influenza in Britain is not notifiable to the Registrar General and its activity is usually gauged by such indices as sickness benefit claims, notifications of pneumonia, and deaths from respiratory disease as well as the publication of laboratory evidence of the disease. Apart from such times as the Christmas and New Year holiday periods, sickness benefit claims are usually a particularly reliable index

* Reprint requests to Dr. D. Reid, Communicable Diseases Unit. Ruchill Hospital, Glasgow G20 9NB. of influenza activity in the community. The certificates to obtain sickness benefit are issued by doctors to patients who require to be off work for a period of more than three days. Broadly, the whole of the civilian working population aged 15 years and over, but not yet retired, can qualify under the National Insurance Act for sickness benefit including not only those employed under contract of service but also the self-employed. Despite the fact that there are over four million employed persons who do not qualify, including about three-and-a-half million married women who elect not to be insured in their own right, and although illness among children and housewives cannot be accounted for in this way, it is recognized that a rise in the recorded number of sicks ness benefit claims during the winter correlates we with the amount of illness in the area ascribed to influenza.

Each week the total number of new sickness benefit claims for various areas is recorded in the Registrar General's weekly return for England and Wales. Also noted in the same publication are the daily recordings of atmospheric temperature at Kew Observatory, Richmond. It has therefore been possible to compare the number of new sickness benefit claims recorded weekly for Greater London with the mean air temperatures in the same area during the winter months of the last five successive years.

\section{RESULTS}

The weekly sickness benefit claims for Greater London and the air temperatures recorded at Kew for the months November to March during the years 1966 to 1971 are given in Tables I to V. The lowest reading of the daily mean air temperatures for the week has been used as the temperature index.

The winter of 1966-67 was remarkable in that influenza did not cause any significant illness (Table I; O Fig. 1). Weekly sickness benefit figures were low and reached a maximum of only 39.2 thousand for the week ending January 10 , the period when the usual artificial inflation after the Christmas and New Year periods would also be included. The absence of in- 
TABLE I

SICKNESS BENEFIT CLAIMS IN GREATER LONL ON COMPARED WITH MEAN AIR TEMPERATURES NOVEMBER 1966 TO FEBRUARY 1967

\begin{tabular}{|c|c|c|}
\hline Week Ending & $\begin{array}{c}\text { Sickness Benefit Claims } \\
\text { (thousands) }\end{array}$ & $\underset{\left({ }^{\circ} \mathbf{C}\right)^{*}}{\text { Air Temperature }}$ \\
\hline 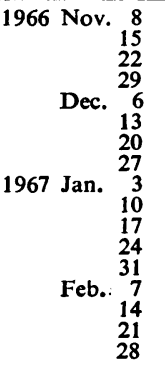 & $\begin{array}{l}32 \cdot 2 \\
34 \cdot 0 \\
32 \cdot 9 \\
32 \cdot 5 \\
32 \cdot 2 \\
29.8 \\
24.9 \\
12 \cdot 0 \\
31 \cdot 8 \\
39 \cdot 2 \\
37.9 \\
35 \cdot 1 \\
32 \cdot 5 \\
30 \cdot 5 \\
29.9 \\
30 \cdot 7 \\
30 \cdot 7\end{array}$ & $\begin{array}{l}4.6 \\
4.7 \\
4.9 \\
1.6 \\
2.7 \\
3.4 \\
3.4 \\
1.1 \\
1.5 \\
-0.6 \\
2.2 \\
5.4 \\
7 \cdot 1 \\
3.3 \\
1.4 \\
4.2 \\
5.2\end{array}$ \\
\hline
\end{tabular}

*Lowest reading of daily mean air temperature for the week.

fluenza is supported by the fact that the highest number of weekly deaths attributed to influenza in England and Wales was only 24 and that laboratory evidence of both influenza virus $A$ and $B$ was also lacking. The winter of 1966-67 was mild; the lowest reading recorded at $\mathrm{Kew}$ was $-0 \cdot 6^{\circ} \mathrm{C}$ and subzero temperatures were reached on only one other occasion.

Both influenza virus $A_{2}$ and $B$ caused illness in the United Kingdom during the following winter. Sickness benefit claims rose steeply during the first week of 1968 and markedly increased figures were recorded throughout January (Table II). The largest weekly number of sickness benefit claims was 83.7 thousand and this was more than double the peak reached in the previous year. Deaths attributed to influenza also rose sharply to 101 during the week

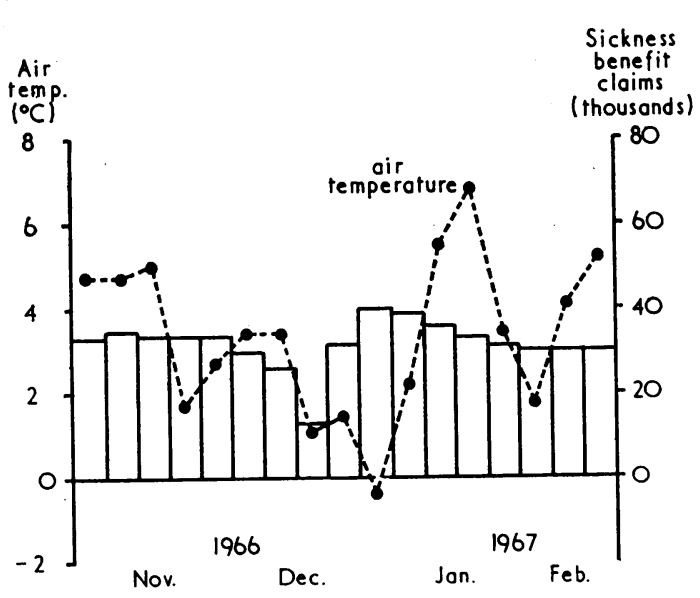

FIG. 1.-Sickness benefit claims and air temperature, 1966-67.
TABLE II

SICKNESS BENEFIT CLAIMS IN GREATER LONDON COMPARED WITH MEAN AIR TEMPERATURES NOVEMBER 1967 TO FEBRUARY 1968

\begin{tabular}{r|c|c}
\hline Week Ending & $\begin{array}{c}\text { Sickness Benefit Claims } \\
\text { (thousands) }\end{array}$ & $\begin{array}{c}\text { Air Temperature } \\
\left({ }^{\circ} \mathbf{C}\right){ }^{*}\end{array}$ \\
\hline 1967 Nov. 7 & $28 \cdot 8$ & $5 \cdot 0$ \\
14 & $30 \cdot 3$ & $3 \cdot 6$ \\
21 & $30 \cdot 2$ & $2 \cdot 7$ \\
28 & $30 \cdot 5$ & $2 \cdot 6$ \\
5 & $32 \cdot 2$ & $5 \cdot 0$ \\
12 & $30 \cdot 8$ & $-2 \cdot 3$ \\
19 & $30 \cdot 9$ & $-0 \cdot 1$ \\
26 & $17 \cdot 0$ & $-1 \cdot 3$ \\
2 & $66 \cdot 1$ & $1 \cdot 6$ \\
9 & $83 \cdot 7$ & $0 \cdot 3$ \\
16 & $62 \cdot 5$ & $-2 \cdot 5$ \\
23 & $44 \cdot 6$ & $1 \cdot 5$ \\
30 & $34 \cdot 3$ & $0 \cdot 5$ \\
6 & $31 \cdot 1$ & $3 \cdot 5$ \\
13 & $33 \cdot 2$ & $2 \cdot 1$ \\
20 & $34 \cdot 5$ & 0.9 \\
27 & $36 \cdot 7$ & \\
\hline 1968 Jan. & \\
\hline
\end{tabular}

*Lowest reading of daily mean air temperature for the week.

ending December 19 and further increased to 287 the following week. The winter was much colder and subzero temperatures were recorded as early as December 8. From this date until January 12 temperatures below $0^{\circ} \mathrm{C}$ were noted on six separate occasions; in addition, the temperature gradient was particularly steep. After a mild November and first week of December, the temperature fell by $6^{\circ} \mathrm{C}$ on December 7 and did not exceed $1^{\circ} \mathrm{C}$ until five days later. At the height of the epidemic, between January 8 and 13 , the temperature did not rise above $1 \cdot 1^{\circ} \mathrm{C}$.

The winter of 1968-69 was made noteworthy by the first isolation in Britain of the new influenza virus variant $A_{2} /$ Hong Kong/68. Despite the fact that the population was presumably largely susceptible, the number of sickness benefit claims recorded during the early part of the winter did not indicate that the new virus had caused more than a moderate amount of illness (Table III). Except for two days (December 13 and 14) in which the temperature fell below $0^{\circ} \mathrm{C}$, mild weather prevailed until December 26, which was the beginning of a period of five days in which the mean daily air temperature did not rise above $1^{\circ} \mathrm{C}$. Sickness benefit claims increased sharply from 16.9 thousand for the week ending December 31 to $46 \cdot 3$ thousand for the following week. Although these returns were inflated by the holiday period, the number of deaths attributed to influenza also rose from 21 during the last week in December to 35 in the first week of January (in a year when influenza is absent from England and Wales, the weekly number of deaths attributed to the disease rarely rises above 20 per week), Laboratory evidence of influenza virus $\mathrm{A}$ also confirmed that the disease was prevalent at that time. However, a long mild spell followed and sickness benefit claims slowly dropped 
TABLE III

SICKNESS BENEFIT CLAIMS IN GREATER LONDON COMPARED WITH MEAN AIR TEMPERATURES NOVEMBER 1968 TO MARCH 1969

\begin{tabular}{|c|c|c|}
\hline Week Ending & $\begin{array}{c}\text { Sickness Benefit Claims } \\
\text { (thousands) }\end{array}$ & Air Temperature \\
\hline $\begin{array}{rr}1968 \text { Nov. } 5 \\
12 \\
19 \\
26 \\
\text { Dec. } 33 \\
10 \\
17 \\
24 \\
31 \\
7969 \text { Jan. } \\
14 \\
21 \\
28 \\
\text { Feb. } 44 \\
11 \\
18 \\
25 \\
\text { Mar. } 4 \\
11 \\
18 \\
25\end{array}$ & $\begin{array}{l}30 \cdot 0 \\
30 \cdot 0 \\
32 \cdot 0 \\
32 \cdot 7 \\
31 \cdot 0 \\
29 \cdot 2 \\
27 \cdot 0 \\
25 \cdot 3 \\
16 \cdot 9 \\
46 \cdot 3 \\
47 \cdot 2 \\
44 \cdot 9 \\
42 \cdot 4 \\
37 \cdot 5 \\
41 \cdot 5 \\
44 \cdot 3 \\
47 \cdot 3 \\
47 \cdot 5 \\
42 \cdot 3 \\
38 \cdot 9 \\
35 \cdot 7\end{array}$ & $\begin{array}{r}4.2 \\
2.5 \\
3.5 \\
7.7 \\
2.9 \\
2.3 \\
-3.1 \\
3.9 \\
-1.0 \\
1.5 \\
2.4 \\
3.1 \\
7.5 \\
0.3 \\
-2.9 \\
-2.6 \\
1.8 \\
1.8 \\
0.2 \\
3.0 \\
2.0\end{array}$ \\
\hline
\end{tabular}

- Lowest reading of daily mean air temperature for the week.

to 37.5 thousand by the week ending February 4 . Colder weather returned on February 3, and four days later the temperature dropped to $-2 \cdot 9^{\circ} \mathrm{C}$. For the next 11 days the mean daily air temperature rose only twice above $1^{\circ} \mathrm{C}$ and during six of these days the temperature was below freezing point. This inclement weather was followed by a rise in sickness benefit claims to over $\mathbf{4 7}$ thousand during the last week in February and the first week in March, nearly 18 thousand more than in the corresponding weeks in 1967 when influenza was absent. Deaths attributed to influenza also rose to 100 during the week ending March 4 and continued to rise during that month.

In October 1969 the new influenza virus variant

TABLE IV

SICKNESS BENEFIT CLAIMS IN GREATER LONDON COMPARED WITH MEAN AIR TEMPERATURES NOVEMBER 1969 TO FEBRUARY 1970

\begin{tabular}{|c|c|c|}
\hline Week Ending & $\begin{array}{c}\text { Sickness Benefit Claims } \\
\text { (thousands) }\end{array}$ & Air Temperature \\
\hline $\begin{array}{rr}1969 \text { Nov. } 4 \\
11 \\
18 \\
25 \\
2 \\
\text { Dec. } \\
9 \\
16 \\
23 \\
30 \\
6 \\
13 \\
20 \\
27 \\
1970 \text { Jan. } \\
\text { Feb. } \\
10 \\
17 \\
24 \\
\text { Mar. } 3\end{array}$ & $\begin{array}{l}26 \cdot 1 \\
25 \cdot 5 \\
27 \cdot 4 \\
28 \cdot 2 \\
28 \cdot 8 \\
37 \cdot 1 \\
49 \cdot 7 \\
59 \cdot 5 \\
37 \cdot 7 \\
93 \cdot 3 \\
83 \cdot 0 \\
48 \cdot 3 \\
33 \cdot 8 \\
28 \cdot 7 \\
28 \cdot 1 \\
28 \cdot 2 \\
31 \cdot 2 \\
28 \cdot 3\end{array}$ & $\begin{array}{r}6.2 \\
4.1 \\
2.1 \\
1.9 \\
-1.5 \\
-0.2 \\
3.6 \\
-1.4 \\
0.2 \\
-4 \cdot 3 \\
-2.5 \\
4.5 \\
4.5 \\
2.1 \\
0.5 \\
-0.9 \\
4.7 \\
0.7\end{array}$ \\
\hline
\end{tabular}

- Lowest reading of daily mean air temperature for the week.

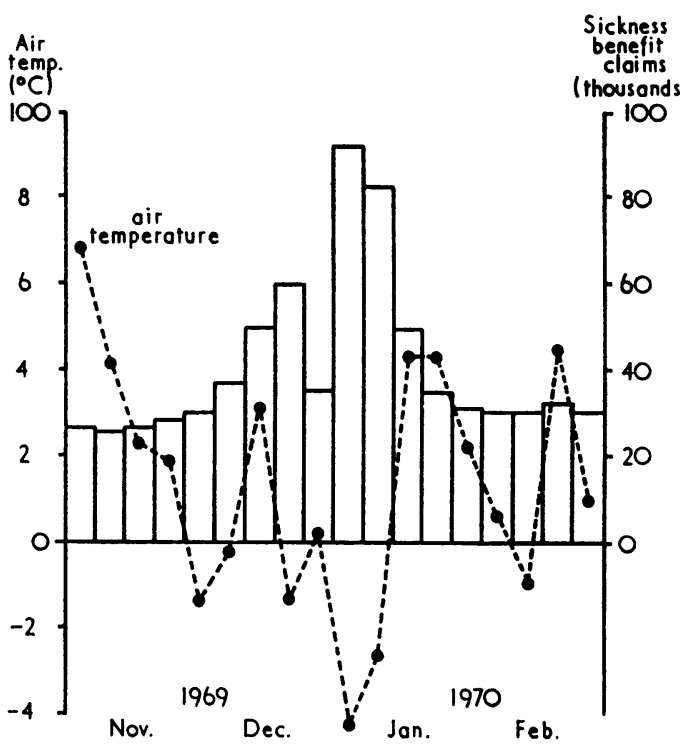

Fig. 2.-Sickness benefit claims and air temperature, 1969-70.

reappeared in the United Kingdom. However, it was not until the beginning of December that the number of sickness benefit claims started to rise and not unt January that the epidemic reached its height. Durints the latter month, however, the number of new claimg outstripped the previous maximum reached during January 1968 and the morbidity produced by the epidemic was similar to that when the $A_{2}$ virus was first introduced into Britain in 1957 (Table IV; Fig. 2). Cold weather started at the end of November and three daily recordings of subzero temperatures were made between November 29 and December 5 . The weather became particularly cold during the first two weeks of 1970 and two of the mean daily temperature readings were lower than any noted during the other four years that were studied. It was during that period that the morbidity from the epidemic was at its height.

The winter of $1970-71$ was generally milder than a year previously. Subzero temperatures were re- 9 corded eight times between November 1970 and the end of February 1971 compared with the 13 occasions during the corresponding months in 1969-70. However, seven of the subzero temperatures noted during the winter of 1970-71 occurred during the 12 days between December 25, 1970 and January 5, 1971 (Table V). There was a small rise in the number of sickness benefit claims to 40 thousand during the week ending January 12 but laboratory surveillance, although showing some influenza virus B activity between February and April, revealed an almost complete absence of illness due to influenza virus 
TABLE V

SICKNESS BENEFIT CLAIMS IN GREATER LONDON COMPARED WITH MEAN AIR TEMPERATURES NOVEMBER 1970 TO FEBRUARY 1971

\begin{tabular}{|c|c|c|}
\hline Week Ending & $\begin{array}{l}\text { Sickness Benefit Claims } \\
\text { (thousands) }\end{array}$ & Air Temperature \\
\hline $\begin{array}{rr}1970 \text { Nov. } 3 \\
10 \\
17 \\
24 \\
\text { Dec. } 1 \\
1 \\
8 \\
15 \\
22 \\
29 \\
5 \\
1971 \text { Jan. } \\
12 \\
19 \\
26 \\
\text { Feb. } 2 \\
9 \\
16 \\
23 \\
\text { Mar. } 2\end{array}$ & $\begin{array}{l}27 \cdot 4 \\
26 \cdot 7 \\
25 \cdot 7 \\
25 \cdot 8 \\
25 \cdot 6 \\
25 \cdot 0 \\
23 \cdot 7 \\
22 \cdot 0 \\
12 \cdot 8 \\
34 \cdot 2 \\
40 \cdot 0 \\
33 \cdot 3 \\
19 \cdot 0 \\
19 \cdot 6 \\
20 \cdot 7 \\
20 \cdot 3 \\
19 \cdot 8 \\
20 \cdot 3\end{array}$ & $\begin{array}{r}12.1 \\
5.0 \\
3.0 \\
3.7 \\
7.9 \\
5.1 \\
-0.2 \\
1.3 \\
-0.7 \\
-2.9 \\
2.7 \\
3.7 \\
6.1 \\
1.1 \\
3.7 \\
1.2 \\
2.9 \\
2.6\end{array}$ \\
\hline
\end{tabular}

*Lowest reading of daily mean air temperature for the week.

A; only seven isolations were reported by the Public Health Laboratory Service between the beginning of November and the end of February.

\section{Discussion}

The reasons for the occurrence of an outbreak of influenza are often obscure and predictions of impending increases in morbidity or absence of the disease are notoriously inaccurate. Doubtless the introduction into a susceptible community of a new variant of the influenza virus usually produces a widespread epidemic, as happened in the United Kingdom in 1957, but this does not always occur. For example, although the variant $\mathrm{A}_{2} /$ Hong Kong/68 was first isolated in various parts of the United Kingdom in 1968, the amount of clinical illness recorded during that winter was much less than expected. Surprisingly, it was not until a year later that large numbers of overt cases occurred when presumably the population was even less susceptible. Therefore, it may be that factors other than the novelty of a virus and the susceptibility of the population are necessary before an outbreak of influenza takes place.

The climatic pattern during the past five winters has varied considerably, ranging from the relatively mild conditions experienced in the winters of 1966-67, 1968-69, and 1970-71 to the more severe winters of 1967-68 and 1969-70. Because the morbidity due to influenza was generally found to be increased during the colder winters and at periods of time shortly following cold spells, it is suggested that atmospheric temperature may be one of the factors influencing the number of clinically apparent infections which take place.

That inconsistencies occur points to a conclusion that no one factor is entirely responsible for an outbreak. For example, between December 25, 1970 and January 5, 1971, subzero temperatures were registered on seven days; however, there was no ensuing outbreak of influenza. The reason may have been that the other factors were not optimal; this was the third season for the $A_{2} /$ Hong Kong/68 virus, and after the severe outbreak of 1969-70 the population may have had sufficient immunity to resist infection.

Several possibilities for an association between influenza and cold weather exist. It may be that during a more severe winter the population tends to stay indoors and the subsequent crowding together may facilitate the spread of influenza virus from one person to another. Hope-Simpson (1958) obtained a good correlation between respiratory infections and decline in temperature; he concluded that the effect of temperature was not a direct one, but that the colder weather caused people to heat their homes and begin to live in conditions of lower relative humidity. Against this explanation are the studies of Schulman and Kilbourne (1962), who investigated the effect of humidity and air movement on the development and transmission of influenza virus in rats. They observed that development and transmission of the virus is accelerated under dry cold conditions with little air movement such as prevail in Europe during winter.

Whatever the explanation, this association may be a useful prognostic index in predicting the effect on the population of the influenza virus. The World Health Organisation has built up a mechanism to make possible an early warning to be given of the appearance of influenza in most of the countries of the world. As long-range weather forecasts are becoming more efficient it may be that we should also consider the likely atmospheric temperatures to be expected during the winter when predicting outbreaks of influenza.

\section{SUMMARY}

During the past five years, winters of greatly differing degrees of severity have occurred in the United Kingdom. There has also been a great variation in the morbidity due to influenza, ranging from that of epidemic proportion to almost complete absence of the disease. A comparison has been made of the number of sickness benefit claims recorded in Greater London with the atmospheric temperature at Kew Gardens, Richmond. During the milder winters of 1966-67, 1968-69, and 1970-71 there were fewer sickness benefit claims than during the more severe winters of 1967-68 and 1969-70.

It is suggested that air temperature may be one of 
the factors which determine the number of cases of influenza occurring in an area.

We wish to thank Professor N. R. Grist and Dr. J. H. Lawson, Department of Infectious Diseases, and Professor T. Anderson, Department of Epidemiology and Preventive Medicine, Ruchill Hospital, Glasgow, for their help in the preparation of this paper; Miss L. Alexander for secretarial assistance; and Mr. J. Waldie, Department of Medical Photography, Stobhill Hospital, Glasgow, for the illustrations.

\section{REFERENCES}

Anderson, T., Grist, N. R., Landsman, J. B., LAIDLAW, S. I. A., and WeIR, I. B. L. (1953). An epidemic of influenza due to virus B. Brit. med. J., $1,7$.
Encyclopaedia Britannica (1970). Vol. 12, p. 24\% William Benton, Chicago.

FARR, W. (1885). Vital Statistics; A Memorial Volume $尹$ Selections from the Reports and Writings of Willia) Farr, edited by N. A. Humphreys, p. 413. Offices of Sanitary Institute, London.

Hope-Simpson, R. E. (1958). Discussion on the common cold. Proc. roy. Soc. Med., 51, 267.

Schulman, J. L., and KilbourNe, E. D. (1962). Aip borne transmission of influenza virus infection in mices Nature (Lond.), 195, 1129.

Semple, A. B. (1951). Epidemiology of the influenza epidemic in Liverpool in 1950-51. Proc. roy. Soc. Med 44, 794. 